\title{
Can ruminal inoculum from slaughtered cattle replace inoculum from cannulated cattle for feed evaluation research?
}

\section{O inóculo ruminal de bovinos abatidos pode substituir o inóculo de bovinos canulados em pesquisas de avaliação de alimentos?}

\author{
Henry Daniel Ruiz Alba ${ }^{1}$; Ronaldo Lopes Oliveira ${ }^{2 *}$; Silvana Teixeira Carvalho ${ }^{3}$; \\ Luís Carlos Vinhas Ítavo"; Ossival Lolato Ribeiro ${ }^{5}$; Nilton Guedes do Nascimento \\ Júnior $^{6}$; Marcondes Dias Freitas ${ }^{6}$; Leilson Rocha Bezerra ${ }^{7}$
}

\begin{abstract}
The objective was to test the hypothesis that ruminal inoculum obtained from slaughtered cattle can replace inoculum from cannulated cattle in trials evaluating animal feedstuffs through in vitro gas production and digestibility. Five adult Holstein $\times$ Zebu steers with ruminal cannula were used to collect and compare rumen liquid from in vivo and slaughtered animals. In vitro dry matter digestibility (IVDMD), in vitro neutral detergent fiber digestibility (IVNDFD) and ammoniacal nitrogen concentrations did not differ between inoculum sources (slaughtered $\times$ cannulated) for all byproducts and levels tested. Total in vitro gas production in the ruminal inoculum of cannulated animals was greater $(P<0.001)$ than slaughtered cattle for different levels of licuri cake. However, the greatest total concentrations of in vitro gases for slaughtered animals were observed when evaluating different levels of crude glycerin $(P<0.001)$. No differences were observed for diets containing castor bean meal $(P>0.05)$. Thus, the ruminal inoculum obtained from the ruminal contents of slaughtered cattle can replace the use of fistulated animals and is a viable alternative to digestibility analysis. This approach is ethically more correct because it alleviates the suffering of animals by avoiding an invasive procedure.
\end{abstract}

Key words: Ammoniac nitrogen. Cannula. Digestibility. pH. Ruminal fermentation.

\section{Resumo}

O objetivo foi testar a hipótese de que o inóculo ruminal obtido a partir de bovino abatido pode substituir o inóculo do bovino canulado em ensaios que avaliam os alimentos para ruminantes através da produção

1 Discente, Curso de Doutorado, Programa de Pós-Graduação em Zootecnia, Universidade Federal da Bahia, PPGZ/UFBA, Salvador, BA, Brasil. E-mail: harrydoo@gmail.com

2 Prof., Departamento de Zootecnia, Escola de Medicina Veterinária e Zootecnia, UFBA, Salvador, BA, Brasil. E-mail: ronaldozootecnista@gmail.com

3 Prof ${ }^{a}$, Departamento de Ciências Agrárias, Universidade Estadual do Oeste do Paraná, UNIOESTE, Campus Marechal Cândido Rondon, PR, Brasil. E-mail: silteixeira@gmail.com

4 Prof., Departamento de Medicina Veterinária e Zootecnia, Universidade Federal de Mato Grosso do Sul, UFMS, Campo Grande, MS, Brasil. E-mail: luis.itavo@ufms.br

5 Prof., Centro de Ciências Agrárias, Ambientais e Biológicas, Universidade Federal do Recôncavo Baiano, UFRB, Cruz das Almas, BA, Brasil. E-mail: ossival@ufrb.edu.br

6 Pós Doutorandos, Programa de Pós-Graduação em Zootecnia, PPGZ/UFBA, Salvador, BA, Brasil, E-mail: niltonguedesjr@ gmail.com; mdfreitasneto@gmail.com

7 Prof., Unidade Académica de Medicina Veterinária, Universidade Federal de Campina Grande, UFCG, Patos, PB, Brasil, E-mail: leilson@ufpi.edu.br

Author for correspondence 
de gás in vitro e digestibilidade. Foram utilizados cinco novilhos adultos Holstein $\times$ Zebu com cânula ruminal para coleta e comparação de líquido ruminal provenientes destes animais in vivo e de animais abatidos. A digestibilidade in vitro da matéria seca (DIVMS) e da fibra em detergente neutro in vitro (DIVFDN) e as concentrações de nitrogênio amoniacal não diferiram entre fontes de inóculo (abatidos $\times$ canulados) para todos os subprodutos e níveis testados. A produção total de gás in vitro no inóculo ruminal de animais canulados foi maior $(P<0,001)$ comparado ao inóculo de animal abatido para os diferentes níveis de torta de licuri. No entanto, as maiores concentrações totais de gás in vitro foram observadas para animais abatidos quando o co-produto utilizado foram níveis de glicerina bruta $(P$ $<0,001)$. Não foram observadas diferenças nas dietas contendo farelo de mamona $(P>0,05)$. Assim, $o$ inóculo ruminal obtido a partir do conteúdo ruminal de bovino abatido pode substituir o uso de animais fistulados, sendo uma alternativa viável para a realização da análise de digestibilidade. Esta abordagem é eticamente mais correta porque alivia o sofrimento dos animais evitando um procedimento invasivo.

Palavras-chave: Cânula. Digestibilidade. Fermentação ruminal. Nitrogênio amoniacal. pH.

\section{Introduction}

The use of animals in scientific research has been a constant practice permeating the history of science, from ancient times to the present (PAIXÃO; SCHRAMM, 1999; PACHECO et al., 2012). Along with the use of animals for various purposes, ethical concerns and questions about the merits of these experiments have grown, as has increasing demands on society for the care and welfare of animals. Although it is a relatively old practice (dating back to the 1920s), the fistulation process (surgically opening a canal between an organ and the outside) and cannulation (inserting a valve into the cavity) of one of the stomach compartments (rumen) of cattle still causes outrage among the public (THYFAULT et al., 1975; CHAUDHRY; MOHAMED, 2012; PACHECO et al., 2012). After all, why would anyone perform this procedure? Does the animal feel pain? Is its life at risk?

Some complications may occur after implantation of permanent cannulas, such as peritonitis and leakage of ruminal contents, which may even lead to death (HARRISON, 1995). Nevertheless, the use of rumen cannula is widespread in the scientific community because the number of animals required is reduced and such techniques reduce costs and provide a reliable method for assessing feed (BERCHIELLI et al., 2005). Additionally, the procedure allows analysis of the digestibility of feed and enables the collection of rumen material for in vitro digestibility trials and in vivo analysis of small samples through in situ digestibility (DAMIRAN et al., 2008). However, the leakage of large amounts of rumen contents can lead to dehydration and malnutrition (GROVUM, 1989). The in vitro fermentation technique proposed by Tilley and Terry (1963) has been widely used to estimate in vivo digestibility, with numerous studies around the world applying the technique to assess the nutritional value of ingredients used in diets for production animals. Nonetheless, this technique utilizes ruminal inoculum, which can lead to variation in results.

The constant handling of an animal affects its welfare, which is a violation of animal care laws (MUTIMURA et al., 2013) and is considered unacceptable by many people and animal protection agencies (CHAUDHRY; MOHAMED, 2012; PÔSSAS et al., 2015). Therefore, many experiments have used alternative sources of ruminal inoculum, such as sheep feces (VÁRADYOVÁ et al., 2005), buffalo feces (CUTRIGNELLI et al., 2005), and buffalo ruminal fluid and sheep ruminal fluid (CALABRÒ et al., 2005), and some have applied different methods of ruminal inoculum conservation (DENEK et al., 2010; HERVÁs et al., 2005). Although in vitro approaches depend on a source of ruminal inoculum (AMMAR et al., 2008), the use of fistulated animals must be phased out and fistulation replaced with other techniques that do 
not cause suffering to animals (CHAUDHRY; MOHAMED, 2012). Accordingly, we hypothesized that the use of ruminal inoculum obtained from slaughtered cattle can replace fistulated animals for use in analyses of gas production, digestibility and parameters of ruminal fermentation for in vitro trials. Thus, the aim of this trial was to compare ruminal inoculum obtained from the rumen of slaughtered and cannulated cattle for use in determining in vitro digestibility and ruminal fermentation parameters of feeds.

\section{Materials and Methods}

\section{Animals and experimental design}

This study was conducted at the Federal University of Bahia, in São Gonçalo dos Campos, Bahia, located at $12^{\circ} 25^{\prime} \mathrm{S}$ and $38^{\circ} 58^{\prime} \mathrm{W}$ and carried out in strict accordance with the recommendations in the Guide for the National Council for the Control of Animal Experimentation (CONCEA) and was approved by the Committee on the Ethics of Animal
Experiments of the Federal University of Bahia, Bahia State, Brazil (Protocol Number: 17-2014).

Five cattle $(\mathrm{n}=5)$ with ruminal cannula and an average body weight of approximately $320 \pm 9.4 \mathrm{~kg}$ were used. At the beginning of the adaption period, the cattle were treated for internal and external parasites (Ranger LA, Ivermectin ${ }^{\circledR}$, dose of 200 $\mathrm{mcg} \mathrm{kg}^{-1}, 1 \mathrm{~mL}$ per $50 \mathrm{~kg}$ of body weight (BW), $3.5 \%$, Salvador, Brazil). The cattle were housed in individual stalls $\left(3 \times 6 \mathrm{~m}^{2}\right)$ with feeders and drinkers.

The experiment was a completely randomized design comparing two sources of ruminal inoculum: ruminal inoculum obtained from cannulated cattle and ruminal inoculum obtained from cattle healthy slaughtered for marketing. To compare the two sources of ruminal inoculum, sixteen different diets representative of conventional ruminant diets (using different proportion of concentrate: forage) containing byproducts from the biodiesel production chain (crude glycerin, licuri cake and castor bean meal) in the concentrate and Tifton-85 (Cynodon sp.) grass hay as forage (Table 1).

Table 1. Chemical composition of the ingredients used in the formulation of the diets.

\begin{tabular}{lcccccc}
\hline $\begin{array}{c}\text { Chemical composition } \\
\left(\mathrm{g} \mathrm{kg}^{-1}, \mathrm{DM}\right)\end{array}$ & $\begin{array}{c}\text { Tifton-85 } \\
\text { hay }\end{array}$ & $\begin{array}{c}\text { Ground } \\
\text { corn }\end{array}$ & $\begin{array}{c}\text { Soybean } \\
\text { meal }\end{array}$ & $\begin{array}{c}\text { Licuri } \\
\text { cake }\end{array}$ & $\begin{array}{c}\text { Castor } \\
\text { bean meal }\end{array}$ & $\begin{array}{c}\text { Crude } \\
\text { glycerin }\end{array}$ \\
\hline Dry matter $\left(\mathrm{g} \mathrm{kg}^{-1}\right.$, as fed $)$ & 880 & 891 & 893 & 930 & 899 & 764 \\
Ash & 73.0 & 14.3 & 75.4 & 51.2 & 82.0 & 139 \\
Crude protein & 87.3 & 80.3 & 490 & 302 & 381 & - \\
Ether extract & 13.0 & 42.0 & 16.0 & 73.0 & 2.00 & 283 \\
${ }_{\text {ap Neutral detergent fiber }}{ }^{\mathrm{b}}$ & 690 & 114 & 128 & 333 & 528 & - \\
Acid detergent fiber & 331 & 26 & 68.3 & 144 & 345 & - \\
Acid detergent lignin & 40.2 & 5.32 & 11.1 & 57.2 & 229 & - \\
Cellulose & 291 & 21.2 & 57.4 & 87.2 & 116 & - \\
Hemicellulose & 358 & 88.2 & 61.3 & 190 & 183 & - \\
Non-fiber carbohydrates & 138 & 751 & 291 & 242 & 7.06 & 577 \\
Total digestive nutrients & 614 & 898 & 797 & 772 & 473 & 716 \\
\hline
\end{tabular}

${ }^{a}$ Corrected for ash and protein.

${ }^{\text {b}}$ Estimated per second NRC (2001). 


\section{Diets and chemical analysis}

The diets contained a mean of $102 \mathrm{~g} \mathrm{~kg}^{-1}$ protein and $337 \mathrm{Mcal}$ of digestible energy $\mathrm{kg}^{-1} \mathrm{DM}$, with a proportion of $400 \mathrm{~g} \mathrm{~kg}^{-1}$ forage (Tifton-85 hay Cynodon sp.) and $600 \mathrm{~g} \mathrm{~kg}^{-1}$ concentrate (ground corn, soybean meal, urea, and mineral mix). Feeding was performed twice daily, at $09 \mathrm{~h} 00$ and $17 \mathrm{~h} 00$. The crude glycerin used contained $266 \mathrm{~g} \mathrm{~kg}^{-1}$ of water, $36 \mathrm{~g} \mathrm{~kg}^{-1}$ of ash, $434 \mathrm{~g} \mathrm{~kg}^{-1}$ of glycerol and $26 \mathrm{~g}$ $\mathrm{kg}^{-1}$ of alcohol. The castor bean meal was detoxified

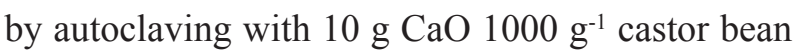
meal for 30 minutes. The composition of the diets and the inclusion levels of the byproducts in the diets are presented in Table 2.

Table 2. Proportional inclusion levels and chemical composition of the experimental diets $\left(\mathrm{g} \mathrm{kg}^{-1} \mathrm{DM}\right)$ with byproducts.

\begin{tabular}{|c|c|c|c|c|c|c|c|c|c|c|c|c|}
\hline \multirow{2}{*}{$\begin{array}{c}\text { Byproducts } \\
\text { Inclusion levels }\end{array}$} & \multicolumn{4}{|c|}{ Crude glycerin $\left(\mathrm{g} \mathrm{kg}^{-1}\right)$} & \multicolumn{4}{|c|}{ Licuri cake $\left(\mathrm{g} \mathrm{kg}^{-1}\right)$} & \multicolumn{4}{|c|}{ Castor bean $\left(\mathrm{g} \mathrm{kg}^{-1}\right)$} \\
\hline & 0 & 70 & 140 & 210 & 0 & 70 & 140 & 210 & 0 & 70 & 140 & 210 \\
\hline \multicolumn{13}{|c|}{ Ingredients proportion $\left(\mathrm{g} \mathrm{kg}^{-1} \mathrm{DM}\right)$} \\
\hline Ground corn & 255 & 167 & 83 & 0 & 498 & 448 & 408 & 368 & 272 & 300 & 280 & 185 \\
\hline Soybean meal & 230 & 248 & 262 & 275 & 80 & 60 & 30 & 0 & 213 & 178 & 65 & 90 \\
\hline Byproducts & 0 & 70 & 140 & 210 & 0 & 70 & 140 & 210 & 0 & 7 & 140 & 210 \\
\hline Urea & 0 & 0 & 0 & 0 & 12 & 12 & 12 & 12 & 0 & 0 & 0 & 0 \\
\hline Mineral mix ${ }^{\mathrm{a}}$ & 15 & 15 & 15 & 15 & 10 & 10 & 10 & 10 & 15 & 15 & 15 & 15 \\
\hline Tifton-85 hay & 500 & 500 & 500 & 500 & 400 & 400 & 400 & 400 & 500 & 500 & 500 & 500 \\
\hline \multicolumn{13}{|c|}{ Chemical composition $\left(\mathrm{g} \mathrm{kg}^{-1} \mathrm{DM}\right)$} \\
\hline Dry matter, as fed & 901 & 874 & 849 & 810 & 899 & 900 & 898 & 898 & 900 & 898 & 900 & 904 \\
\hline Ash & 64 & 64 & 66 & 58 & 45 & 45 & 43 & 48 & 60 & 61 & 62 & 66 \\
\hline Crude protein & 162 & 184 & 183 & 193 & 163 & 160 & 159 & 150 & 174 & 174 & 175 & 163 \\
\hline Ether extract & 10.0 & 22.0 & 31.0 & 42.0 & 8.00 & 16 & 16 & 22 & 9.00 & 7.00 & 7.00 & 5.00 \\
\hline $\mathrm{NDF}^{\mathrm{b}}$ & 471 & 446 & 465 & 462 & 383 & 422 & 426 & 432 & 477 & 470 & 527 & 532 \\
\hline $\mathrm{ADF}^{\mathrm{c}}$ & 196 & 213 & 220 & 225 & 153 & 175 & 179 & 183 & 200 & 232 & 260 & 291 \\
\hline $\mathrm{ADL}^{\mathrm{d}}$ & 27 & 25 & 27 & 27 & 16 & 24 & 25 & 28 & 22 & 57 & 78 & 100 \\
\hline Cellulose & 169 & 188 & 193 & 198 & 137 & 151 & 155 & 156 & 177 & 175 & 183 & 191 \\
\hline Hemicellulose & 275 & 233 & 245 & 238 & 230 & 247 & 247 & 248 & 277 & 239 & 266 & 242 \\
\hline $\mathrm{NFC}^{\mathrm{e}}$ & 293 & 284 & 255 & 245 & 401 & 358 & 356 & 349 & 281 & 288 & 230 & 234 \\
\hline $\mathrm{TDN}^{\mathrm{f}}$ & 696 & 734 & 751 & 717 & 728 & 735 & 733 & 728 & 701 & 640 & 601 & 568 \\
\hline
\end{tabular}

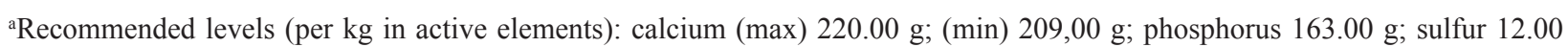
g; magnesium $12.50 \mathrm{~g}$; copper 3,500,00 mg; cobalt $310.00 \mathrm{mg}$; iron 1,960.00 mg; iodine $280.00 \mathrm{mg}$; manganese 3,640.00 mg; selenium, $32.00 \mathrm{mg}$; zinc 9,000.00 mg; and fluorine (max) 1,630.00 mg.

bNeutral detergent fiber corrected for ash and protein.

${ }^{\mathrm{c}} \mathrm{ADF}=$ acid detergent fiber.

${ }^{\mathrm{d}} \mathrm{ADL}=$ acid detergent lignin.

eNFC: Non-fiber carbohydrates.

${ }^{\mathrm{f}}$ Total digestible nutrients estimated per second, NRC (2001).

The samples of feeds $(n=3)$ used to compose the experimental diets were dried in a forced-air oven at $55^{\circ} \mathrm{C}$ for $72 \mathrm{~h}$. All feeds were then processed in a Wiley knife mill using 1-mm sieves and analyzed according to the Association of Official Methods of Analysis (AOAC, 1990) for dry matter (DM, method 967.03), ash (method 942.05), crude protein (CP, method 981.10), and ether extract (EE, method 920.29). The content of neutral detergent fiber (NDF) was determined according to Van Soest et 
al. (1991) and included the residual ash; heat-stable alpha-amylase was not used. The acid detergent fiber (ADF) content was determined according to Robertson and Van Soest (1981). The acid detergent lignin content was determined according to AOAC (2002) method 973.18 in which the ADF residue was treated with $72 \%$ sulfuric acid. We also analyzed neutral detergent insoluble nitrogen (NDIN) and the acid detergent insoluble nitrogen (ADIN) according to Licitra et al. (1996). Increases in NDIP and ADIP contents were calculated by multiplying the NDIN and ADIN concentrations, respectively, by 6.25. Non-fiber carbohydrates (NFC) content was calculated according to (MERTENS, 1997) by the equation $\mathrm{NFC}=\left(100-\mathrm{CP}+\mathrm{EE}+\mathrm{Ash}+{ }_{\text {ap }} \mathrm{NDF}\right)$ in $\mathrm{g} \mathrm{kg}^{-1}$. The total digestible nutrient (TDN) contents were calculated according to estimation formulas of digestibility for each analytical fraction (NRC, 2001): $\mathrm{DNFC}=0.98 \times(\mathrm{NFC}) ; \mathrm{DCP}=\mathrm{CP} \times[1-(0.4$ $\times \mathrm{ADIP} / \mathrm{CP})] ; \mathrm{DEE}=\mathrm{EE}-1 ; \mathrm{DNDF}=0.75 \times(\mathrm{NDF}$ - Lignin $) \times[1-($ Lignin $/ \mathrm{NDF}) \times 0.667]-7$, where DNFC is the digestible non-fibrous carbohydrates, DCP indicates digestible crude protein, DEE is the digestible ether extract, DNDF is the digestible neutral detergent fiber, and NDF is the neutral detergent fiber.

\section{Buffer, slaughter and rumen fluid preparation}

A buffer solution at $\mathrm{pH} 6.8$, constant temperature of $39^{\circ} \mathrm{C}$ and saturated with $\mathrm{CO}_{2}$ was prepared with a mixture of Solution A and Solution B. Solution A $\left(\mathrm{g} \mathrm{L}^{-1}\right)$ was composed of $10 \mathrm{~g} \mathrm{KH}_{2} \mathrm{PO}_{4}, 0.5 \mathrm{~g}$ $\mathrm{MgSO}_{4} \cdot 7 \mathrm{H}_{2} \mathrm{O}, 0.5 \mathrm{~g} \mathrm{NaCl}, 0.1 \mathrm{~g} \mathrm{CaCl}_{2} \cdot 2 \mathrm{H}_{2} \mathrm{O}$ and $0.5 \mathrm{~g}$ urea. Solution B (g $\left.100 \mathrm{~mL}^{-1}\right)$ was composed of $15.0 \mathrm{~g} \mathrm{Na}_{2} \mathrm{CO}$ and $1.0 \mathrm{~g} \mathrm{Na} \mathrm{S}_{2} \mathrm{~S} \cdot 9 \mathrm{H}_{2} \mathrm{O}$. Solutions A and $B$ were mixed at a ratio of 1:0.02 (A:B), i.e., 20 mL Solution B:1000 mL Solution A.

For the cannulated cattle $(n=5)$, the ruminal content was collected two hours before the morning feeding (07h00). Four liters of ruminal contents per animal were collected in preheated thermal bottles with water at $39^{\circ} \mathrm{C}$; the ruminal contents were constantly purged with $\mathrm{CO}_{2}$. The ruminal contents collected were composed of a solid fraction (collected from the 6 points of the rumen) and a liquid fraction (collected with the help of a vacuum pump, preheated and purged constantly with $\mathrm{CO}_{2}$ ) of the same proportion; approximately two liters of each fraction were obtained. The ruminal content of the five animals was mixed, producing the ruminal inoculum for in vitro incubations.

The alternative inoculum source was collected from five $(n=5)$ different slaughtered cattle in a slaughterhouse; these cattle had been fasted from water and solids for $12 \mathrm{~h}$. The origin of this group was unknown; therefore, the feeding and handling was unknown but assumed to include tropical grasses and mineral supplementation.

The cattle were slaughtered by captive bolt without electrical stimulation, exsanguinated; the hides were removed, and the animals were eviscerated. The ruminal contents of this group were collected from the gastrointestinal tract in the washing room between 7 to 15 minutes after stunning. Four liters of ruminal contents were collected into a 1.5 -L preheated jug with water at $39^{\circ} \mathrm{C}$, and the contents were purged constantly with $\mathrm{CO}_{2}$.

After the ruminal contents were placed in thermal bottles $(n=3)$, the collected material was processed as ruminal inoculum. The collected material of all animals was homogenized in a 1:1 ratio (solid fraction:liquid fraction) for 10 seconds using a blender, pre-heated, and constantly purged with $\mathrm{CO}_{2}$. The homogenate was then filtered through four layers of cotton fabric (gauze) and used for incubations. The ruminal content of the slaughtered cattle was mixed, producing ruminal inoculum for in vitro incubations.

\section{In vitro incubations}

The in vitro dry matter digestibility (IVDMD) of the diets was determined using an artificial 
rumen (Ankom ${ }^{\circledR}$ Ruminal Fermenter, «DaisyII Fermenter," Ankom Technológic Corp., USA) according to Holden (1999). A total of $0.5 \mathrm{~g}$ of each diet $(n=3)$ was placed into TNT-100 $\mathrm{g} \mathrm{m}^{-1}$ bags, which were then cut and sealed $(5.0 \mathrm{~cm} \times$ $5.0 \mathrm{~cm}$ ) according to Casali et al. (2008). Two bags without samples (white) were also used. The bags with samples were evenly distributed into jars (previously heated and purged with $\mathrm{CO}_{2}$ ), with 26 bags jar ${ }^{-1}$ ( 24 with a sample and 2 white) for a total of 104 bags. Then, $1600 \mathrm{~mL}$ of buffer solution and 400 $\mathrm{mL}$ of ruminal inoculum were added under $\mathrm{CO}_{2}$ to maintain anaerobic conditions. After this procedure, the jars remained in the DaisyII Fermenter artificial rumen at $39^{\circ} \mathrm{C}$ for $48 \mathrm{~h}$. For white, they were used bags with samples using ingredients known as standards (soybean and corn) with IVDMD already known (control) to confirm proper digestion of the samples tested. The digestion of the standards was performed every three sessions of incubation of the experiment diets, to verify and correct possible variations or problems in the incubation. However, no variation or error were observed.

After $48 \mathrm{~h}, 40 \mathrm{~mL}$ of $\mathrm{HCl}(6 \mathrm{~N})$ and $8 \mathrm{~g}$ pepsin (Sigma 1:10000) were added. In an attempt to maintain the $\mathrm{pH}$ of the solution between 2.0 and 3.5 , the pepsin was dissolved in $34 \mathrm{~mL}$ distilled $\mathrm{H}_{2} \mathrm{O}$ at $35^{\circ} \mathrm{C}$ for 5 minutes (HOLDEN, 1999). The incubation was continued for an additional $24 \mathrm{~h}$ at $39^{\circ} \mathrm{C}$, after which the bags were washed with tap water until the water ran clean. The bags were then pre-dried in forced-air ovens at $55^{\circ} \mathrm{C}$ for $12 \mathrm{~h}$, dried in an oven at $105^{\circ} \mathrm{C}$ for $16 \mathrm{~h}$ and weighed. After drying, the bags with dry sample were analyzed to determine NDF content (VAN SOEST et al., 1991).

Finalized the in vitro dry matter digestibility assay, the DaisyII Fermenter incubator $\left(39^{\circ} \mathrm{C}\right)$ was used to assess the parameters of ruminal fermentation. For each jar (caps were fitted with three track taps), $10 \mathrm{~g}$ of sample was weighed, and $1600 \mathrm{~mL}$ of buffer solution and $400 \mathrm{~mL}$ of ruminal inoculum were added. At $0,2,4,6$, and $8 \mathrm{~h}$ after the start of incubation, a sample of $20 \mathrm{~mL}$ of buffered ruminal fluid was collected; $10 \mathrm{~mL}$ of buffered ruminal fluid was stored in plastic pots, and the Kjeldahl method was used to measure ammoniac nitrogen (SOUZA et al., 2013).

\section{Calculations and Statistical Analysis}

In vitro dry matter digestibility (IVDMD) was calculated using the residue remaining after incubation with the following formula (ANKOM TECHNOLOGY, 2005):

$$
I V D M D=100-W_{3} \times\left[\left(W_{1} \times \mathrm{W}_{4}\right) / W_{2}\right] \times 100
$$

Where $\mathrm{W}_{1}$ is the tare weight of the bag, $\mathrm{W}_{2}$ is the weight of the dry sample, $\mathrm{W}_{3}$ is the weight of the final bag, and W4 is the correction with the white bag. In vitro neutral detergent fiber digestibility (IVNDFD) was calculated with the residue after assessing NDF residue using the formula:

$$
I V N D F D=100-W_{7} \times\left[\left(\mathrm{W}_{5} \times \mathrm{W}_{8}\right) / W_{6}\right] \times 100
$$

Where $\mathrm{W}_{5}$ is the tare weight of the bag, $\mathrm{W}_{6}$ is the weight of the NDF of the sample, $\mathrm{W}_{7}$ is the final weight of the bag after the NDF, and $\mathrm{W}_{8}$ is the correction with the white bag. Analysis of variance was performed on data, and when the difference was significant, Student's t-test at $5 \%$ probability was applied using SAS v. 9.1.3 (2008) statistical software (SAS® Inst. Inc., Cary, NC).

\section{Results}

Dry matter (IVDMD) and neutral detergent fiber digestibility (IVNDFD)

No difference in IVDMD and IVNDFD with respect to the source of ruminal inoculum $(P>0.05)$ was observed for all byproducts and levels. The mean concentration of $\mathrm{NH}_{3}-\mathrm{N}$ of the different byproducts and all levels incubated presented no differences $(P$ $>0.05$ ) between ruminal inoculum from cannulated animals and slaughtered cattle (Table 3). 
Table 3. Comparison between inoculum obtained from slaughtered cattle and cannulated cattle for in vitro digestibility variables.

\begin{tabular}{|c|c|c|c|c|c|c|c|c|c|c|c|c|}
\hline Level & Crude g & ycerin & SEM $^{\mathrm{a}}$ & P-value ${ }^{b}$ & Licur & Cake & SEM $^{\mathrm{a}}$ & $\mathrm{P}$-value ${ }^{b}$ & \multicolumn{2}{|c|}{ Castor bean meal } & SEM $^{\mathrm{a}}$ & P-value \\
\hline \multicolumn{13}{|c|}{ In vitro dry matter digestibility (IVDMD) } \\
\hline $0 \%$ & 0.86 & 0.85 & 0.25 & 1.00 & 0.83 & 0.83 & 0.23 & 1.00 & 0.82 & 0.81 & 0.19 & 0.995 \\
\hline $7 \%$ & 0.85 & 0.84 & 0.17 & 1.00 & 0.83 & 0.82 & 0.33 & 0.96 & 0.79 & 0.78 & 0.15 & 1.000 \\
\hline $14 \%$ & 0.82 & 0.83 & 0.16 & 0.99 & 0.82 & 0.83 & 0.27 & 0.99 & 0.76 & 0.74 & 0.30 & 0.656 \\
\hline $21 \%$ & 0.81 & 0.83 & 0.12 & 1.00 & 0.83 & 0.83 & 0.30 & 0.19 & 0.71 & 0.70 & 0.24 & 0.983 \\
\hline \multicolumn{13}{|c|}{ In vitro neutral detergent fiber digestibility (IVNDFD) } \\
\hline $0 \%$ & 0.65 & 0.63 & 0.55 & 0.996 & 0.67 & 0.68 & 0.50 & 1.00 & 0.65 & 0.63 & 0.36 & 1.000 \\
\hline $7 \%$ & 0.68 & 0.65 & 0.73 & 0.83 & 0.65 & 0.65 & 0.34 & 1.00 & 0.59 & 0.57 & 0.30 & 1.000 \\
\hline $14 \%$ & 0.60 & 0.63 & 0.58 & 0.98 & 0.65 & 0.67 & 0.31 & 0.99 & 0.58 & 0.55 & 0.52 & 0.925 \\
\hline $21 \%$ & 0.58 & 0.63 & 0.66 & 0.05 & 0.67 & 0.67 & 0.22 & 1.00 & 0.51 & 0.49 & 0.41 & 0.994 \\
\hline \multicolumn{13}{|c|}{ In vitro concentrations of ammoniacal nitrogen $\left(\mathrm{NH}_{3}-\mathrm{N}\right)$} \\
\hline $0 \%$ & 164 & 122 & 14.6 & 0.84 & 130 & 111 & 13.6 & 0.99 & 117 & 120 & 11.4 & 1.000 \\
\hline $7 \%$ & 159 & 119 & 14.7 & 0.87 & 147 & 114 & 14.9 & 0.96 & 130 & 125 & 12.7 & 1.000 \\
\hline $14 \%$ & 147 & 132 & 13.3 & 1.00 & 160 & 105 & 16.4 & 0.62 & 152 & 141 & 14.9 & 1.000 \\
\hline $21 \%$ & 153 & 144 & 14.2 & 1.00 & 161 & 116 & 16.3 & 0.83 & 169 & 131 & 15.2 & 0.887 \\
\hline
\end{tabular}

${ }^{a}$ Standard error of the mean.

${ }^{b}$ Means followed by lowercase letters differ significantly according to Student's t-test at $1 \%$ and $5 \%$ probabilities.

\section{Gas production}

Total in vitro gas production in ruminal inoculum was greater from cannulated animals $(P$ $<0.001)$ regarding to slaughtered cattle for licuri cake $0 ; 7$ and $14 \%$ inclusion level diets, except for the inclusion level of $21 \%$ when slaughtered animals inoculum showed greater concentrations of gases in vitro (Table 4). However, the greatest total concentrations of gases in vitro for slaughtered than cannulated animals were observed when evaluating different levels of crude glycerin $(P<0.001)$. No differences were observed for diets with inclusion levels of castor bean meal $(P>0.05)$.

Table 4. Comparison between inoculum obtained from slaughtered cattle and cannulated cattle for total in vitro gas production $(\mathrm{mL})$.

\begin{tabular}{cccccc}
\hline Byproduct & Inclusion level & Cannulated & Slaughtered & SEM $^{\mathrm{a}}$ & $P$-value \\
\hline \multirow{3}{*}{ Crude glycerin } & $0 \%$ & $12.8 \mathrm{~b}$ & $14.8 \mathrm{a}$ & 0.27 & $<0.001$ \\
& $7 \%$ & $10.2 \mathrm{~b}$ & $12.6 \mathrm{a}$ & 0.26 & $<0.001$ \\
& $14 \%$ & $9.20 \mathrm{~b}$ & $12.4 \mathrm{a}$ & 0.36 & $<0.001$ \\
& $21 \%$ & $8.60 \mathrm{~b}$ & $11.4 \mathrm{a}$ & 0.26 & $<0.001$ \\
\hline \multirow{2}{*}{ Licuri Cake } & $0 \%$ & $15.0 \mathrm{a}$ & $12.7 \mathrm{~b}$ & 0.39 & $<0.001$ \\
& $7 \%$ & $14.4 \mathrm{a}$ & $13.0 \mathrm{~b}$ & 0.41 & $<0.001$ \\
& $14 \%$ & $14.5 \mathrm{a}$ & $11.9 \mathrm{~b}$ & 0.35 & $<0.001$ \\
& $21 \%$ & $10.8 \mathrm{~b}$ & $11.7 \mathrm{a}$ & 0.38 & 0.033 \\
\hline
\end{tabular}


continuation

\begin{tabular}{lccccc}
\hline & $0 \%$ & 10.9 & 9.20 & 0.36 & 0.052 \\
Castor bean meal & $7 \%$ & 10.3 & 10.2 & 0.41 & 0.150 \\
& $14 \%$ & 9.00 & 9.00 & 0.44 & 0.084 \\
& $21 \%$ & $8.80 \mathrm{a}$ & $7.10 \mathrm{~b}$ & 0.13 & 0.066 \\
\hline
\end{tabular}

a Standard error of the mean.

${ }^{b}$ Means followed by lowercase letters differ significantly according to Student's t-test at $5 \%$ probabilities.

\section{Discussion}

The results for IVDMD, IVNDFD and $\mathrm{N}^{-\mathrm{NH}_{3}}$ demonstrate that the use of ruminal inoculum from slaughtered animals is an interesting alternative to the use of cannulated animals because among all feed sources used, only one did not present similar results when comparing the two inoculum sources. In planning a research project, all ethical issues surrounding animal rights as well as the specific physiological characteristics of each species should be considered. The aim is to guarantee the welfare of animals during the experiment as a way to eliminate any discomfort that may be caused (CRISSIUMA; ALMEIDA, 2006).

In general, differences with respect to $\mathrm{pH}$ may be related to anaerobiosis, which is essential when isolating and culturing rumen microorganisms (HUNGATE, 1966). In addition, a decrease in both cellulolytic and amylolytic activities (LEEDLE; HESPELL, 1983) and a decline in ciliate protozoan abundance occur if an anaerobic environment is not sustained. Therefore, the inoculum should not be exposed to air, even short-term exposure; equally important, any increase in headspace pressure should not be so great as to force the $\mathrm{CO}_{2}$ into the solution.

Decreased in vitro gas production was found for the use of inoculum source from slaughtered cattle, likely due to the presence of air during storage and the temperature making it difficult for the rumen microorganisms to degrade NDF.

Robinson et al. (1999) used the Ankom ${ }^{\circledR}$ endpoint system to verify the effect of within-day delays of $0.5,2.5,4.5$ and $6.5 \mathrm{~h}$ between collection of rumen fluid from a cow and initiation of in vitro fermentation, as well as storage of rumen fluid for $48 \mathrm{~h}$ at either $-24^{\circ} \mathrm{C}$ or 6,22 and $39^{\circ} \mathrm{C}$, on IVNDFD at $48 \mathrm{~h}$ was determined. The results of the authors demonstrated that this bulk in vitro procedure resulted in higher $48 \mathrm{~h}$ digestion of NDF than those determined with a similar in sacco procedure, thereby suggesting that laboratories located some distance from the donor animal can utilize in vitro procedures to accurately estimate $48 \mathrm{~h}$ digestion of NDF.

Concerns of animal welfare and the ethical issues of animal use in scientific experiments have prompted serious discussions between researchers and members of animal-protective societies. These debates intensified mainly at the beginning of nineteenth century when the number of entities and groups concerned with animal welfare increased substantially (RAYMUNDO; GOLDIM, 2002). Pressure from these groups on scientists, teaching and research institutions, and the rulers of a number of countries had created ethical criteria for publishing the results of animal research through editorial policies, thus revealing growing concern for animal rights in the scientific community (PAIXÃO; SCHRAMM, 1999), as well as the creation or update of laws regulating the use of animals in scientific experiments. Since Tilley and Terry (1963) developed the in vitro digestibility technique, millions of fistulated animals have been used for inoculum in research related to ruminant animal nutrition. Therefore, the possibility of using animal sources of inoculum that do not cause injury 
to animals should be promoted and increasingly tested.

According to Rymer et al. (2005), the driving force has been either to reduce the use of surgically modified animals and/or to provide a more standardized inoculum than is possible with variable rumen fluid. However, as observed in this study, with the exception of crude glycerin, the use of inoculum from slaughtered animals reduced the in vitro production of gases, which may have occurred due to the type of feed the animals received, and consequently modified the pattern of liquid rumen microorganisms. When evaluating feces as inoculum in potential gas production, Mauricio et al. (2001) observed difference from ruminal liquid, with the former showing poorer fermentation capacity compared to ruminal liquid and gas volumes always being lower and often with substantially less volume. The authors concluded that fecal matter has potential as an alternative inoculum to rumen liquor for the in vitro gas production technique of Theodorou et al. (1994). However, the results obtained show a consistently longer lag phase when using the feces-based inoculum, in agreement with previous studies applying technique of the Menke et al. (1979).

Rumen contents harvested post-slaughter offer the benefit of no surgical preparation, though there is no possibility of examining animal effects (MOULD et al., 2005). In comparison to sampling a ruminally cannulated animal, which will have had access to feed, the practice of offering a minimal amount of feed and water prior to slaughter will negatively affect the microbial quality of the resulting rumen fluid inoculum (BORBA et al., 2001). Although the use of slaughterhouse waste allows sufficient material to be collected for a series of studies, thereby limiting variation among incubations conducted over time, this approach requires that the material be stored under conditions that will minimize the loss of microbial activity (MOULD et al., 2005).
The use of fistulated animals should be avoided, as these animals are often sick. Regardless, we believe that this discussion about the use of ruminal fistulas must be continued because despite the concern for establishing rules and parameters for evaluating the welfare of farm animals, little has been discussed in academic circles about the animals welfare used in scientific experiments and teaching. Although animals undergoing this procedure receive prophylactic antibiotics postoperatively in order to avoid infections, there may be surgical complications, discomfort, stress or clinical signs of discomfort or pain, proving the procedure if not used safely can be abusive about animal welfare preservation.

Even so, we are aware that the technique of fistulated animals is essential in studies of physiology and metabolism of rumen. From this, it is possible to obtain detailed knowledge of the digestive process and to carry out dietary assessments, feed passage rate, determinations of chemical parameters involved in digestion $(\mathrm{pH}$, ammoniacal nitrogen, volatile fatty acids, among other utilities) and development of strategies for enteric methane mitigation. All these assessments provide key information for the sustainability of livestock. However, replacement of the rumen cannula with alternative ruminal liquid from slaughtered animals may increase animal welfare without prejudice to scientific research.

\section{Conclusions}

Ruminal inoculum obtained from the ruminal contents of slaughtered cattle can replace the use of ruminal fistula and is a viable alternative for digestibility analysis because the material was found to be efficient for almost all feed sources at all levels studied in this work; results were comparable to those obtained using inoculum from fistulated animals. Nonetheless, variations on in vitro gas analysis were observed using the ruminal contents 
from slaughtered animals and fistulated animals. In addition, details of the slaughtered animal with respect to diet and nutrition are needed.

\section{Acknowledgements}

The authors thank the National Council for Scientific and Technological Development $(\mathrm{CNPq}$ Brazil) for the financial support.

\section{References}

AMMAR, H.; LÓPEZ, S.; ANDRÉS, S.; RANILLA, M. J.; BODAS, R.; GONZÁLEZ, J. S. In vitro digestibility and fermentation kinetics of some browse plants using sheep or goat rumen fluid as the source of inoculum. Animal Feed Science and Technology, Amsterdam, v. 147, n. 1-3, p. 90-104, 2008.

ANKOM TECHNOLOGY. In vitro true digestibility using the DAISY ${ }^{\mathrm{II}}$ Incubator. Macedon, NY: ANKOM Technology, 2005. Available at: <https://www.ankom. $\mathrm{com} /$ sites/default/files/document-files/IVDMD_ 0805 D200.pdf $>$. Accessed at: 2 july 2018 .

ASSOCIATION OF OFFICIAL ANALYTICAL CHEMISTS - AOAC. Official methods of analysis. Gaithersburg: Official methods of analysis of AOAC International, 2002.

Official methods of analysis. Washington:

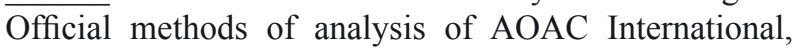
1990.

BERCHIELLI, T. T.; OLIVEIRA, S. G.; GARCIA, A. V. Application of techniques for intake, diet composition and digestibility studies. Archives of Veterinary Science, Curitiba, v. 10, n. 2, p. 29-40, 2005.

BORBA, A. E. S.; CORREIA, P. J. A.; FERNANDES, J. M. M.; BORBA, A. F. R. S. Comparison of three sources of inoculum for predicting apparent digestibility of ruminant feedstuffs. Animal Research, Les Ulis, v. 50, n. 4, p. 265-273, 2001.

CALABRÒ, S.; LÓPEZ, S.; PICCOLO, V.; DIJKSTRA, J.; DHANOA, M. S.; FRANCE, J. Comparative analysis of gas production profiles obtained with buffalo and sheep ruminal fluid as the source of inoculum. Animal Feed Science and Technology, Amsterdam, v. 123-124, p. 51-65, 2005.

CASALI, A. O.; DETMANN, E.; VALADARES FILHO, S. C.; PEREIRA, J. C.; HENRIQUES, L. T.; FREITAS, S. G.; PAULINO, M. F. Influence of incubation time and particles size on indigestible compounds contents in cattle feeds and feces obtained by in situ procedures. Revista Brasileira de Zootecnia, Viçosa, MG, v. 37, n. 2, p. 335-342, 2008.

CHAUDHRY, A. S.; MOHAMED, R. A. I. Fresh or frozen rumen contents from slaughtered cattle to estimate in vitro degradation of two contrasting feeds. Czech Journal of Animal Science, Prague, v. 57, n. 6, p. 265273, 2012.

CRISSIUMA, A. L.;ALMEIDA, E. C. P. Experimentation and welfare - review article. Revista de Saúde e Meio Ambiente, Três Lagoas, v. 1, p. 1-10, 2006.

CUTRIGNELLI, M. I.; CALABRÒ, S.; TUDISCO, R.; ZICARELLI, F.; GAZANEO, M. P.; PICCOLO, V. Comparison of buffalo rumen liquor and buffalo faeces as inoculum for the in vitro gas production technique. Italian Journal of Animal Science, Bologna, v. 4, n. p. 319-321, 2005. Suplemento 2.

DAMIRAN, D.; DELCURTO, T.; BOHNERT, D. W.; FINDHOLTC, S. L. Comparison of techniques and grinding size to estimate digestibility of forage based ruminant diets. Animal Feed Science and Technology, Amsterdam, v. 141, n.1-2, p. 15-35, 2008.

DENEK, N.; CAN, A.; AVCI, M. Frozen rumen fluid as microbial inoculum in the two - stage in vitro digestibility assay of ruminant feeds. South African Journal of Animal Science, Pretoria, v. 40, n. 3, p. 251-256, 2010.

GROVUM, W. L. An improved rumen cannulation technique to minimize leakage. Acta Veterinaria Scandinavica, London, v. 86, p. 225-228, 1989.

HARRISON, F. A. Surgical techniques in experimental farm animals. Oxford: Oxford University, 1995, 617p.

HERVÁS, G.; FRUTOS, P.; GIRÁLDEZ, F. J.; MORA, M. J.; FERNÁNDEZ, B.; MANTECÓN, Á. R. Effect of preservation on fermentative activity of rumen fluid inoculum for in vitro gas production techniques. Animal Feed Science and Technology, Amsterdam, v. 123-124, p. 107-118, 2005.

HOLDEN, L. A. Comparison of methods of in vitro matter digestibility for ten feeds. Journal of Dairy Science, Champaign, v. 82, n. 8, p. 1791-1794, 1999.

HUNGATE, R. E. The rumen and its microbes. New York: Academic Press, 1966. 532 p.

LEEDLE, J. A.; HESPELL, R. B. Changes of bacterial numbers and carbohydrate fermenting groups during in vitro rumen incubations with feedstuff materials. Journal of Dairy Science, Champaign, v. 67, n. 4, p. 808-816, 1983.

LICITRA, G.; HERNANDEZ, T. M.; VAN SOEST, P. J. 
Standartization of procedures for nitrogen fractionation of ruminants feeds. Animal Feed Science and Technology, Amsterdam, v. 57, n. 4, p. 347-358, 1996.

MAURICIO, R. M.; OWEN, E.; MOULD, F. L.; GIVENS, I.; THEODOROU, M. K.; FRANCE, J.; DAVIES, D. R.; DHANOA, M. S. Comparison of bovine rumen liquor and bovine faeces as inoculum for an in vitro gas production technique for evaluating forages. Animal Feed Science and Technology, Amsterdam, v. 89, n. 1-2, p. 33-48, 2001.

MENKE, K. H.; RAAB, L.; SALEWSKI, A.; STEINGASS, H.; FRITZ, D.; SCHNEIDER, W. The estimation of the digestibility and metabolisable energy content of ruminant feeding stuffs from the gas production when they are incubated with rumen liquor in vitro. The Journal of Agricultural Science, London, v. 93, n. 1, p. 217-222, 1979.

MERTENS, D. R. Creating a system for meeting the fiber requirements of dairy cows. Journal of Dairy Science, Champaign, v. 80, n. 7, p. 1463-1481, 1997.

MOULD, F. L.; KLIEM, K. E.; MORGAN, R.; MAURICIO, R. M. In vitro microbial inoculum: a review of its function and properties. Animal Feed Science and Technology, Amsterdam, v. 123-124, p. 31-50, 2005.

MUTIMURA, M.; MYAMBI, C. B.; GAHUNGA, P.; MGHENI, D. M.; LASWAI, G. H.; MTENGA, L. A.; GAHAKWA, D.; KIMAMBO, A. E.; EBONG, C. Rumen liquor from slaughtered cattle as a source of inoculum for in vitro gas production technique in forage evaluation. Agricultural Journal, Dubai, v. 8, n. 4, p. 173-180, 2013.

NUTRITIONAL REQUIREMENTS COUNCIL - NRC. Nutrient requirements of beef cattle. $7^{\text {th }}$ revised ed. Washington: National Academic Press, 2001.

PACHECO, G. F. E.; SAAD, F. M. O. B.; TREVIZAN, L. Ethical issues in the use of animal production in scientific experiments. Acta Veterinaria Brasilica, Mossoró, v. 6, n. 4, p. 260-266, 2012.

PAIXÃO, R. L.; SCHRAMM, F. R. Ethics and animal experimentation: what is debated? Caderno de Saúde Pública, Rio de Janeiro, v. 15, p. 99-111, 1999.

PÔSSAS, F. P.; GONÇALVES, L. C.; PEREIRA, L. G. R.; MACHADO, F. S.; JAYME, D. G.; RODRIGUES, J. A. S.; RODRIGUEZ, N. M.; TOMICH, T. R. Ruminal fermentation kinetics of corn silages from three commercial hybrids at different maturation stages. Arquivo Brasileiro de Medicina Veterinária e Zootecnia, Belo Horizonte, v. 67, n. 1, p. 159-165, 2015.

RAYMUNDO, M. M.; GOLDIM, J. R. Ethics of research in animal models. Bioética, Brasília, v. 10, p. 31-44, 2002.
ROBERTSON, J. B.; VAN SOEST, P. J. The detergent system of analysis and its application in human foods. In: JAMES, W. P. T.; THEANDER, O. (Ed.). Analysis of dietary fiber in food. New York: Marcell Dekker Inc., 1981. p. 123-158.

ROBINSON, P. H.; MATHEWS, M. C.; FADEL, J. G. Influence of storage time and temperature on in vitro digestion of neutral detergent fiber at $48 \mathrm{~h}$, and composition to $48 \mathrm{~h}$ in sacco neutral detergent fiber digestion. Animal Feed Science and Technology, Amsterdam, v. 80, n. 3-4, p. 257-266, 1999.

RYMER, C.; HUNTINGTON, J. A.; WILliAMS, B. A.; GIVENS, D. I. In vitro cumulative gas production techniques: history, methodological considerations and challenges. Animal Feed Science and Technology, Amsterdam, v. 123-124, p. 9-30, 2005.

SOUZA, N. K. P.; DETMANN, E.; VALADARES FILHO, S. C.; COSTA, V. A. C.; PINA, D. S.; GOMES, D. I.; QUEIROZ, A. C.; MANTOVANII, H. C. Accuracy of the estimates of ammonia concentration in rumen fluid using different analytical methods. Arquivo Brasileiro de Medicina Veterinária e Zootecnia, Belo Horizonte, v. 65, n. 6, p. 1752-1758, 2013.

STATISTICAL ANALYSIS SYSTEM INSTITUTE SAS. SAS User's Guide: Statistics. 9. $2^{\text {th }}$ ed. Cary: SAS Institute Inc., 2008.

THEODOROU, M. K.; WILLIAMS, B. A.; DHANOA, M. S.; MCALLAN, A. B.; FRANCE, J. A. A simple gas production method using a pressure transducer to determine the fermentation kinetics of ruminant feeds. Animal Feed Science and Technology, Amsterdam, v. 48, n. 3-4, p. $185-197,1994$.

THYFAULT, H. A.; LEFFEL, E. C.; HUANG, M. D. Simplified method for producing permanent ruminal fistulae. Journal of Dairy Science, Lancaster, v. 58, n. 12, p. 1899-1901, 1975.

TILLEY, W. H.; TERRY, R. A. A two stage technique for in vitro digestion of forage crops. Grass and Forage Science, London, v. 8, n. 2, p. 104-111, 1963.

VAN SOEST, P. J.; ROBERTSON, J. B.; LEWIS, B. A. Methods for dietary fiber, neutral detergent fiber, and nonstarch polysaccharides in relation to animal nutrition. Journal of Dairy Science, Champaign, v. 74, n.10, p. 3583-3597, 1991.

VÁRADYOVÁ, Z; BARAN, M.; ZELENÁK, I. Comparison of two in vitro fermentation gas production methods using both rumen fluid and faecal inoculum from sheep. Animal Feed Science and Technology, Amsterdam, v. 123-124, p. 81-94, 2005. 
